2000

\title{
The Future Debate on Multidisciplinary Practice in the United States
}

Sydney M. Cone III.

New York Law School, sydney.cone@nyls.edu

Follow this and additional works at: http://digitalcommons.nyls.edu/fac_articles_chapters

Part of the Law and Economics Commons, Legal Education Commons, and the Legal Profession Commons

\section{Recommended Citation}

2 Eur. J.L. Reform 611 (2000)

This Article is brought to you for free and open access by the Faculty Scholarship at DigitalCommons@NYLS. It has been accepted for inclusion in Articles \& Chapters by an authorized administrator of DigitalCommons@NYLS. 


\title{
The Future Debate on Multidisciplinary Practice in the United States
}

\author{
Sydney M. Cone, III*
}

\section{A. Introduction}

On 11 July 2000, the American Bar Association (ABA), through its House of Delegates, took two votes relating to multidisciplinary practice (MDP), which effectively repudiated the position recommended by the American Bar Association's (ABA) Commission on MDP (the ABA Commission). The first vote rejected a procedural motion, supported by the ABA Commission to defer a vote on the merits. The second vote approved a Recommendation sponsored by several state bar associations which were substantively opposed to the position of the ABA Commission. The second vote also put an end to the existence of the ABA Commission. ${ }^{1}$

For two years, the ABA Commission had been seeking to persuade the House of Delegates to approve MDP in what might be called its ultimate form - a form whereby non-legal professionals would be permitted to own legal practices. In 1999, the ABA Commission proposed that such an MDP should be permitted, provided it was required to certify annually to a state court that it had complied with the rules governing the legal profession, and was subject to 'administrative audit' by the court. $^{2}$ In 2000, the ABA Commission, abandoning its 1999 approach, indicated that compliance with those rules by such an MDP '[could] be satisfied in a variety of

* C.V. Starr, Professor of Law, New York Law School, Attorney at Law, New York; Counsel and former partner, Cleary, Gottlieb, Steen \& Hamilton, Vice Chairman of the NYSBA Special Committee on the Law Governing Firm Structure and Operation.

1 The motion to defer was defeated by a vote of 262 against, 152 for. The second vote was on a Recommendation (in the form of Report $10 \mathrm{~F}$ to the House of Delegates) by bar associations of (in alphabetical order) Florida, Illinois, New Jersey, New York, and Ohio. It was approved by a vote of 314 in favour, 106 against. It is summarized in the text two paragraphs below.

2 ABA Commission, Report No. 109 to the House of Delegates, issued in June and dated August 1999. On 10 August 1999, the House of Delegates declined to adopt the Report and, by a vote of 304 to 98, resolved that no change should be made in the Model Rules of Professional Conduct as they relate to MDP 'unless and until additional study demonstrates that such changes will further the public interest ....

European Journal of Law Reform, Vol. 2, No. 4

(C) Kluwer Law International 2000. 
ways', and effectively recommended that the several states select from amongst that variety the way or ways that the states deemed best. ${ }^{3}$

Neither the 1999 nor the 2000 proposal of the ABA Commission was voted on as such by the House of Delegates. Instead, by approving resolutions proposed by state bar groups, the House indicated that the proposals of the ABA Commission were inadequate. In 1999, the House cited a need for more study of the issues relating to MDP and the legal profession. In 2000, the House adopted a more detailed resolution clearly disapproving - as incompatible with the "core values of the legal profession' - of MDPs in respect of which non-lawyers or non-legal entities 'have any ownership or investment interest in, or managerial or supervisory right, power or position in connection with, the practice of law by any lawyer or law firm'. ${ }^{4}$

The votes by the House of Delegates, while decisive, may not prove to be definitive. Within the American legal profession, the MDP debate can be expected to continue against the background of the steps taken by the House. Of these steps, perhaps more important than the House's indication that the ABA Commission had failed to come up with adequate proposals, was the House's removal of the ABA Commission from the debate - a step that may encourage lawyers within both the $\mathrm{ABA}$ and state bar groups to become more analytical in dealing with MDP.

The MDP debate in the US has focused in large part on two different types of MDP:

- One type has its economic centre of gravity in a sponsoring non-legal professional firm, notably one of the firms known as the Big Five, ${ }^{5}$ seeking to extend its activities to include the practice of law.

- The other type comprises a variety of MDPs proposed by legal practitioners seeking to combine the practice of law with other professional activities.

Conceptually, these two types of MDP overlap. As a practical matter, however, they are rather different, and it is this difference which the ABA Commission largely failed to analyze, and which may inform the future debate.

The difference turns on the likelihood of whether the practice of law in the MDP will be effectively controlled by lawyers or non-lawyers. In an MDP whose economic centre of gravity lies within a preponderantly dominant non-legal entity, that entity's dominance alone may dictate that the locus of control of legal practice by the MDP will reside with non-lawyers. In contrast, in MDPs of the second type, legal practitioners may be more likely to control or exercise ultimate influence over the economics of the MDP and thus of its legal practice.

The question of economic control of legal practice becomes highly pertinent in the context of the rules governing the legal profession, and the place of that profession in

3

ABA Commission, Recommendation and Report to the House of Delegates, 12 May 2000; see especially paras 4 and 6 of the Report.

4 See supra note 1.

5 The Big Five are Arthur Andersen; Deloitte Touche Tohmatsu; Ernst \& Young; KPMG; PricewaterhouseCoopers. 
the legal system. Put simply, the question becomes: to what extent is it reasonable to expect MDPs of each type to act in furtherance of those rules and that system?

The ABA Commission did not ignore this question. It simply did not deal with it in a way suggesting that it had received complete and coherent analysis. The approach adopted by the ABA Commission seems to have been to consider submissions made to it by persons appearing before it, but to produce no published synthesis of those submissions, and to refrain from announcing the norms and procedures used by it in evaluating the submissions and reaching its conclusions.

The gap in this process was the absence of any published analysis connecting the submissions generated outside the ABA Commission with the conclusions reached within it. Thus, the various ways and contexts in which economic control by nonlawyers might impinge on the professional conduct of lawyers and on the legal system itself (although covered in some of the submissions received by the ABA Commission) went essentially unexamined in the Reports and Recommendations produced by the ABA Commission. Most importantly, the ABA Commission made no effort to deal with the difference between the two types of MDP mentioned above, that is, between an MDP sponsored by an economically dominant non-legal entity, on the one hand, and, on the other, MDPs in which legal professionals would be likely to exercise economic control or ultimate economic influence in managing legal practice by the MDP.

This analytical gap produced a fatal discontinuity between the ABA Commission's apparent conclusion and its recommendations. In essence, it seems to have concluded that 'an MDP that was not controlled by lawyers might, if left to its own devices, be less likely than a law firm to create a firm 'culture' that was supportive of strict observance of the rules of professional conduct'. ${ }^{6}$ Thus stated, the problem was how to assure, in an MDP controlled by non-lawyers, strict observance of the rules of professional conduct applicable to legal practice by the MDP. In 1999 (as mentioned above), the ABA Commission proposed that such an MDP would certify annually to a court that it had complied with those rules, and that such an MDP would be subject to 'administrative audit' by the court. This recommendation lacked a realistic connection with the problem it presumably was seeking to solve. Widely viewed as a clumsy contrivance not readily susceptible of legislative or judicial application, this recommendation was withdrawn by the ABA Commission in 2000 . The Commission then failed to come up with any specific recommendation for solving the problem inherent in its own conclusion (as discussed above).

The problem inherent in the apparent conclusion of the ABA Commission may lie in the duality of its objectives. First, it insisted on authorizing MDP in what might be called its ultimate form (that is, as mentioned above, MDPs in which legal practice is effectively owned by economically dominant non-legal entities). Secondly, it aspired to

6 It is necessary to look outside the official texts issued by the ABA Commission to find a statement of its conclusion on this key point. The quoted language is from an article written by a member of the ABA Commission, Steven C. Nelson. It is the lead article in the Summer 1999 issue of an ABA publication, International Law News. 
strict observance of the rules of professional conduct applicable to legal practice. The failure of the ABA Commission to come up with a specific recommendation in 2000 may simply reflect its failure to resolve the contradictory nature of its dual objective.

Against this background, the following section examines certain schools of thought that have found expression in the MDP debate in the US.

\section{B. US Schools of Thought Relating to MDP}

Five of the schools of thought in the US on issues involving MDP and the practice of law are: the law and economics school; the approach advocated by the Big Five, which would attach legal professional responsibility to individual lawyers but not their MDP employers; the statement of the Association of the Bar of the City of New York, favouring MDPs deemed to be in the public interest; the flatly negative approach adopted by several state bar associations; and analysis grounded in the law governing lawyers, as developed in a report by the New York State Bar Association. They are examined in order below.

\section{The Law and Economics School}

The approach toward MDP advocated by the law and economics school, briefly stated, is that the availability of legal services to consumers should be dictated by the marketplace, unrestricted by barriers in the form of rules governing the legal profession. Those rules are viewed as 'no different from [those of] any other trade union or interest group pursuing economic protectionism'. Advocates of those rules are said to be 'lawyers defending their economic turf'?

There is a certain intellectual purity to this school of thought. It holds that the ownership of legal practice should be viewed primarily as a function of economic determinism. Thus, whenever legal practitioners or public authorities adopt regulatory measures relating to the practice of law, they should subordinate those measures to the principle of free movement of capital into the practice of law.

It should be noted that the law and economics school is quite selective in its choice of economic considerations that may be taken into account when one is dealing with legal practice. The paramount economic consideration (according to this school) is freedom of ownership and investment, uncomplicated by any consideration of how this freedom may produce different professional consequences in different economic

7 The quotations are from, respectively, Daniel R. Fischel, 'Multidisciplinary Practice, Seminar in Law and Economics' at Harvard Law School, 21 March 2000; and testimony of James C. Turner before the ABA Commission. For the view that protectionism motivates the legal profession in its reaction to MDP, see also, Tunku Varadarajan, 'Why is the ABA Afraid of a Little Competition for Lawyers?' (2000) Wall Street Journal, at A27, 24 July. 
contexts. In particular, this school is indifferent to potential variation in professional consequences flowing from the economics of ownership when legal practices are owned by, respectively:

(1) lawyers;

(2) conglomerate professional enterprises controlled by non-lawyers; and

(3) non-professional investors.

Strictly speaking, this school of thought is not concerned with multidisciplinarity, but with the ownership of legal practice in any context, be it unidisciplinary (a conventional stand-alone legal practice), or multidisciplinary (a legal practice integrated with other professional disciplines), or polycommercial (a legal practice integrated with other business pursuits). The premise of freedom of ownership of legal practice, thus espoused, is that the market will determine, efficiently and appropriately, which form of ownership is to be rewarded by consumers purchasing legal services. In order for the market to perform this function, consumers of legal services, it is argued, must be free to acquire them from legal practices owned in those forms that the market elects to reward.

The law and economics school, being essentially unconcerned with multidisciplinarity, would permit non-professional investors to become owners of legal practices. ${ }^{8}$ It thus would carry the concept of integration beyond the type of integrated MDP proposed by the ABA Commission in its 1999 and 2000 Reports (referred to above), and would permit passive portfolio investors, as well as nonprofessional business or commercial enterprises, to own or invest in the practice of law. (The ABA Commission stated in its Reports that it was opposed to nonprofessional ownership of, or passive investment in, legal practice. ${ }^{9}$ ) Were the views of the law and economics school to be adopted, banks, insurance companies, retail enterprises, travel agencies, business conglomerates (among others) could acquire law firms; and law firms themselves would be free to issue their own equity securities to outside investors through private placements or public offerings.

The potential reach of law and economics thinking is thus quite extensive. To realize its potential, this school of thought would not encumber itself unduly with questions of reconciling non-lawyer control of legal practice with legal rules of professional ethics. It is (as mentioned above) a philosophy of considerable intellectual purity, ordaining that professional rules must simply give way whenever their enforcement would impinge upon the mobility of capital investment into the practice of law. It seems safe to observe that attaining this level of purity in practice transforming law and economics theory into a matrix of legal practice - would require substantial modification of existing rules governing the practice of law.

8 A seminal work in this respect is Adams and Matheson, 'Law Firms on the Big Board?: A Proposal for Non-lawyer Investment in Law Firms' (1998) 86 Calif L Rev 1.

9 For a study of MDP reaching the opposite conclusion and recommending passive investment in law firms in France, see the Rapport Nallet, Les Réseaux Pluridisciplinaires et les Professions du Droit (Paris, 1999). 


\section{The Approach Advocated by the Big Five}

The views of the Big Five on MDP are a subset of law and economics doctrine - a subset tailored, quite understandably, to their own business objectives. ${ }^{10}$ In light of those objectives, the Big Five do not seem to espouse investment by non-professionals in the practice of law. Rather, the approach of the Big Five seems limited to seeking those changes in rules of the legal profession necessary to accommodate the acquisition and control of legal practices by the Big Five themselves, that is, by those professions other than law, notably accounting, in which the Big Five now engage or might engage in the future. On the other hand, it seems clear that the Big Five intend to own and control legal practices within integrated MDPs in which non-lawyers would have, and lawyers would not have, a preponderant economic interest and ultimate decision-making authority. Thus, a major objective of the Big Five is to modify or eliminate, as necessary, professional rules that inhibit or prohibit nonlawyers from owning, investing in, or controlling legal practices - that is, to change those rules in a manner that would permit non-legal professionals and non-legal professional entities to own, invest in, and control firms engaged in the practice of law, and to create integrated MDPs subsuming legal practices.

Such changes have been resisted by the legal profession including (as discussed above) by the ABA House of Delegates, on the ground that they would threaten the core values of the legal profession. In the Recommendation adopted by the House on 11 July 2000 , these values were expressed as including the following duties of the lawyer:

(1) to manifest undivided loyalty to the client;

(2) competently to exercise independent legal judgment for the benefit of the client;

(3) to hold client confidences inviolate;

(4) to avoid conflicts of interest with the client;

(5) to help maintain a single profession of law, with responsibilities as a representative of clients, an officer of the legal system, and as a public citizen having special responsibility for the quality of justice.

The Big Five (apart from suggesting, along with the law and economics school, that concern for professional core values is window-dressing for professional protection-

${ }^{10}$ Sources used in arriving at the views of the Big Five on MDP include: testimony before the ABA Commission, particularly that of Kathryn Oberly of Ernst \& Young on 4 February 1999; the July 1999 statement of the Big Five on the 1999 Report of the ABA Commission (entitled, 'By Dramatically Expanding the Definition of the "Practice of Law", the MDP Commission Transforms Bar Associations into Super-Regulators with Vast Control over Industries and Organizations Never Before Subject to Lawyers' Rules and Bar Discipline'); and Big Five papers issued outside the US, particularly Juri-Avenir, 'Répondre aux Attentes du Marché: un Plan d'Action Qualité pour l'Audit en Europe' (1996); Juri-Avenir, 'L'Exercice de la Profession d'Avocat en Réseau Pluridisciplinaire' (1998). 
ism), have argued that the duties referred to in the preceding paragraph are the duties of individual lawyers acting in an individual professional capacity, and are not duties binding on a Big Five firm, as such, when it employs lawyers held out to the public as engaging in the practice of law. This position of the Big Five represents a crucial point in the American debate over MDP. Were it to be adopted, a non-legal entity (such as a Big Five firm) engaged in the practice of law would be exonerated from the professional discipline to which individual lawyers are held. ${ }^{11}$

This argument - that only individual lawyers, but not non-legal entities controlling legal practices, should be subject to the rules governing the legal profession - has served to focus attention on two features of proposals for MDPs owned or otherwise controlled by non-lawyers. The first was jurisdictional: while legal practitioners are subject to supervision and discipline by the courts, no mechanism exists for giving the courts jurisdiction over non-lawyers controlling legal practices, or even for determining what constitutes such control. The second was substantive: if, in respect of their control of legal practices, non-legal entities were to be subject to professional rules and discipline, what would be the content of those rules and of measures relating to their enforcement?

The Big Five, by declining to come forward with suggestions that would facilitate resolving these issues, were themselves seen to be engaged in a form of protectionism. Their argument that only their individual lawyers would be subject to the rules and discipline of the legal profession could be characterized as, first, an argument for protecting themselves against the rules and discipline of the very profession whose economic benefits they sought by proposing to offer legal services to the general public, and, second, an attempt to put those individual lawyers at risk for carrying out the business plans of their employers. Critics of the Big Five position foresaw tensions between the non-lawyers with ultimate authority over a Big Five MDP but no accountability under the rules governing the legal profession, and the lawyers in a subordinate position within the MDP responsible for helping to realize those business plans by offering legal services to the public, while charged with respecting the rules of their profession applicable to such services.

These tensions were most apparent in the debate over whether legal professional rules on conflicts of interest would apply throughout an integrated Big Five MDP offering legal services to the public. The Big Five argued that they should not be subject to legal conflicts rules, and should be permitted to handle conflicting assignments by using internal devices, known as screens or Chinese Walls, that would separate a firm's professionals handling one client's problems from that firm's professionals handling the problems of a client with interests conflicting with those of the first client. This argument was met with considerable skepticism by legal rules governing the legal profession. See NY Disciplinary Rules 1-104(a) and 5-105(e), 29 McKinney's Consolidated Laws of New York. On this and related points generally, see Bernard Wolfman's Testimony to the ABA Commission, 12 March 1999. 
commentators, who were able to point to contemporaneous court decisions rejecting as ethically inadequate such internal screening by the Big Five. ${ }^{12}$

One commentator suggested that the type of legal practice being sought by the Big Five could be accommodated by creating a two-tier legal profession. ${ }^{13}$ Legal practices fully subject to the rules governing the practice of law would in effect constitute a separate profession, and the only profession entitled to hold itself out as fully protective of the interests of its clients. MDP legal practices that offered a lesser level of client protection would not be entitled to hold themselves out as full-fledged members of the legal profession. This proposal has not found substantial support in the course of the MDP debate, but provides a striking illustration of the issues raised by the debate.

\section{Statement by the New York City Bar Association}

In July 1999, the Association of the Bar of the City of New York (ABCNY) issued a statement on MDP which it affirmed in June 2000 (the ABCNY Statement). ${ }^{14}$ The ABCNY Statement generally endorsed MDP and the position thereon taken in 1999 by the ABA Commission, but contained two special features that merit comment in the overall context of the American debate on MDP.

First, the ABCNY Statement de-emphasized MDPs comprising accountants and lawyers, that is, MDPs advocated by the Big Five. (Similarly, the ABA Commission in its Reports played down Big Five MDPs and emphasized small MDPs of lawyers and non-lawyers acting as advisers to the elderly. The hearings held by the ABA Commission, however, made it clear that it was dealing in major part with Big Five MDPs. In contrast, the ABCNY held no hearings and, in its internal deliberations, limited to two committees, did not focus on MDPs involving the Big Five.)

Secondly, the ABCNY suggested that the answer to the question of what professional rules would apply to MDPs could be found in a synthesis of the different professional rules governing the different professions deemed eligible to

12 E.g., UK House of Lords Opinions of the Lords of Appeal for Judgment in the Cause Prince Jefri Bolkiah v. KPMG (18 November and 18 December 1998). A more recent case in which Ernst \& Young's French law firm found itself on both sides of a case and faced disqualification by a US federal court is discussed Tax Notes, 31 July 2000, pp. 611-16. Senior staff members of the US Securities and Exchange Commission (SEC) have also taken a position inconsistent with Big Five views on conflicts of interest. Letter to the President of the ABA from the Chief Counsel, Chief Accountant, and the Director of Enforcement of the SEC, 12 July 1999. See also 'Auditory discomfort' (2000) The Economist, at p. 78 (15 January).

Statement of L. Harold Levinson to the New York State Bar Association, 13 May 1999.

14 Statement of Position on Multidisciplinary Practice, 'The Record of the ABCNY' (1999), at p. 585, September/October. The author, a member of the ABCNY's Special Committee on MDP, dissented from reaffirmation of the ABCNY Statement in 2000. Among other things he found it curious that the ABCNY in 2000, unlike the ABA Commission in 2000, continued to endorse the 1999 position of the ABA Commission. 
form MDPs. The MDPs envisaged by the ABCNY would include, in addition to lawyers, such professionals as architects, environmental engineers, and social workers. (The ABCNY Statement did not purport to set out an exhaustive list of MDP-eligible professions, nor did it propose criteria for the selection of professions that might be included on such a list.) The ABCNY Statement urged the ABA (not the $\mathrm{ABCNY}$ itself, but the $\mathrm{ABA}$ ), in co-ordination with other professional bodies, to develop a common set of professional rules that might govern MDPs. For its part, the ABA has shown little inclination to undertake this task. Were it to do so, it presumably would initiate a programme for:

(1) devising a series of rules that would apply to various MDPs comprising specified professions; and

(2) identifying and granting authority to the bodies responsible for enforcing those rules.

The ABCNY proposal is grounded in the conviction that a social need exists for, e.g., MDPs comprising lawyers and social workers, and that the legal profession has a corresponding duty to fill this need. The clients of such an MDP would, presumably, be entitled to the protections inherent in the fiduciary relationship of lawyer to client - or, as it is frequently put, the protections inherent in the core values of the legal profession. Thus, the umbrella professional rules for an MDP comprising lawyers and social workers would need to protect client confidences, to assure loyalty to clients, to avoid conflicts of interest, to safeguard the lawyer's competence and the independence of the lawyer's judgment in handling legal matters for the client, and to take appropriate account of the lawyer's role in the legal system.

With respect to the ABCNY example of an MDP comprising lawyers and social workers, it seems possible that the social workers might have to be treated as affiliated with the lawyers for purposes of applying legal professional standards of the type just adverted to. In addition, legislative or judicial action might be required in order to subject all of the professionals in such an MDP to the supervisory and disciplinary authority of an administrative or judicial body. In brief, if it is assumed that the ABCNY has properly identified a compelling social need (or a congeries of compelling social needs represented by an aggregate of MDPs involving various professions), considerable work may be involved in developing:

(1) suitable rules for the professionals in an MDB attempting to fulfill the social goals in question; and

(2) means for assuring their enforcement.

In the case of MDPs involving the Big Five, the Big Five themselves (so long as they continue to think they will find it advantageous to offer legal services to the public) can be expected to devote their own resources, and may cause others to devote resources, to questions involving the types of integrated MDP that are of interest to them. It is less clear, however, that commensurate resources will be devoted to promoting the types of MDP advocated by the ABCNY. Issuing a statement 
describing a perceived social need is not the same thing as undertaking the steps required (or thought to be required) in order to fill that social need. It remains to be seen whether the objectives sought by the ABCNY will attract the resources needed to realize those objectives.

\section{The Flatly Negative School Regarding MDP}

Bar associations in several US jurisdictions seem prepared to oppose for the foreseeable future any changes whatsoever in the rules governing the legal profession if the changes would permit MDP. In terms of intellectual purity, this school of thought, the flatly negative school, ${ }^{15}$ is the opposing counterpart to the law and economics school (discussed above). The flatly negative school sees any involvement of non-lawyers in the practice of law as a threat to the core values of the legal profession (as outlined in Report 10F adopted, as discussed above, on $11 \mathrm{July} 2000$ by the ABA House of Delegates), that is, as a threat which, if realized, would bring about a substantial erosion of those values.

Flat negativism is often too simplistic to be maintained in the face of the realities of legal practice. One of these realities is that lawyers, in order to practice law, often need to engage the professional or other services of non-lawyers - services of various types (those, for example, of environmental engineers) subsumed in the debate over MDP. It is not uncommon for lawyers and law firms to carry out their work with the aid of ancillary arrangements involving such non-legal services. Many US states countenance these arrangements, and in some cases have adopted legal professional rules that permit them. ${ }^{16}$

In addition, such ancillary arrangements not only are often necessary for the effective practice of law, but also can shade into difficult conceptual areas not readily dealt with through flat negativism in respect of MDP. An MDP that is effectively the economic preserve of lawyers is, analytically, not readily distinguishable from the law firm that uses non-lawyer professionals in carrying out its legal practice. The enforcement of flat negativism, moreover, requires the enforcer to have always at hand a workable and relevant definition of the practice of law; and such a definition has often proved elusive. ${ }^{17}$

Flat negativism also invites direct confrontations between its advocates and the advocates of MDP. These confrontations might in theory be winnable on the basis of the forceful logic and professional rules of the former (of advocates defending the legal profession and opposing MDP), but these confrontations might in practice turn into strategic contests winnable less through logic than by raw economic power. Advocates of MDP might in fact prefer to deal with flat negativism than with a more

15 What is herein called the flatly negative school is popularly referred to as the 'just say no' school.

16 E.g., Pennsylvania Rules of Professional Conduct, Rule 5.7.

17 See, e.g., Washington State Bar Association, Committee to Define the Practice of Law, 'Final Report', 13 July 1999. 
sophisticated appreciation of the issues relating to MDP. Seeking out points of weakness in the doctrine of flat negativism and throwing substantial economic resources into disputes involving those points of weakness, the advocates of MDP might find it possible to characterize the legal profession as in fact unduly protectionist, and thereby to win judicial or legislative support for measures favourable to MDP.

\section{The April 2000 Report of the New York State Bar Association}

Beginning in June 1999, the New York State Bar Association (NYSBA) had been concerned about perceived analytical deficiencies in the work of the ABA Commission and, in July 1999, the NYSBA had created its own Special Committee on the Law Governing Firm Structure and Operation (the NYSBA Committee). ${ }^{18}$ In April 2000, the NYSBA Committee issued its Report entitled 'Preserving the Core Values of the Legal Profession: The Place of Multidisciplinary Practice in the Law Governing Lawyers' (the NYSBA Report). ${ }^{19}$

As the title of the NYSBA Report suggests, it approaches MDP from the point of view of the law governing lawyers in the US - not only statutes and professional rules, but also the considerable body of judge-made law constituting much of the common law of legal practice. Its announced purpose is to present a study of the factual predicates of the MDP debate, and to make specific recommendations as to what should and should not be changed in the law governing lawyers in order, in the public interest, to clarify the place of MDP in that law while, at the same time, preserving the core values of the legal profession.

The NYSBA Report considers ownership of legal practice to constitute control of legal practice, and recommends that MDP not be permitted in a form in which nonlawyers would have ownership or investment interests. ${ }^{20}$ The form of MDP recommended by the NYSBA Report (in addition to lawyer ownership of services ancillary to the practice of law) ${ }^{21}$ is a so-called 'side-by-side' affiliation. This (as set out in the NYSBA Report) is an affiliation in which a law firm and a non-legal professional service firm enter into and maintain a contractual relationship for the purpose of offering to the public, on a systematic and continuing basis, legal services

18 The NYSBA Committee has 12 members, plus advisors and liaison officials. Robert MacCrate is its Chair; the current President-elect of the NYSBA, Steven C. Krane, and the author are its Vice Chairs; John D. Leubsdorf is its Reporter.

19 The NYSBA Report (pp. 388 et seq. and appendices) is obtainable from the NYSBA, Albany, NY.

20 Non-lawyers and non-legal professional service firms affiliated with lawyers and law firms would not be permitted 'to obtain, hold or exercise, directly or indirectly, any ownership or investment interest in, or managerial or supervisory right, power or position in connection with, the practice of law by the lawyer or law firm'. The term 'ownership or investment interest' is defined to include 'any form of debt or equity'. Proposed New York Disciplinary Rule 1-107(A)(2), (B)(2), NYSBA Report, at pp. 352-353.

21 See ibid., at pp. 336-337 (proposed New York Disciplinary Rule 1-106). 
performed by the law firm, as well as other professional services. The NYSBA Report makes it clear, however, that, in such an affiliation between a law firm and a non-legal professional service firm, the latter should not be permitted to play a role in deciding whether to provide legal services in a particular matter or to a particular client, or in the hiring and training of lawyers, or in assigning lawyers to handle particular matters, or in decisions relating to pro bono publico and other publicinterest legal work, or in financial matters relating to legal practice, or in the compensation or advancement of lawyers. ${ }^{22}$

As thus proposed by the NYSBA Report, a 'side-by-side' MDP falls far short of the type of integrated MDP sought by the Big Five (as discussed above), yet represents a significant departure from the school that is flatly opposed to any form of MDP (as also discussed above). Thus, the NYSBA Report would seem designed to make unhappy both the strongest of the proponents of integrated MDPs (the Big Five $^{23}$ and the law and economics school), and the opponents to any type of MDP. (It has also failed to win the support of the ABCNY, which, since July 1999, has declined to abandon the June 1999 position of the ABA Commission (abandoned by the Commission itself in 2000), and which seems unable to adapt to the reality presented by the issuance of the NYSBA Report.

Despite its seemingly having arrived on the scene to present a displeasing target to a wide array of participants in the US debate on MDP, the NYSBA Report rather clearly played a positive role in the deliberations of the ABA House of Delegates leading up to the adoption, on 11 July 2000, of a Recommendation by the House consonant with the NYSBA Report, and the simultaneous termination of the ABA Commission by the House. There would seem to be two explanations for the positive role of the NYSBA Report in this regard. First, it filled the analytical vacuum created by the work of the ABA Commission in 1999 and 2000, and in particular was responsive to the call by the ABA House of Delegates, on 10 August 1999, for 'additional study' of the issues relating to MDP. ${ }^{24}$ (The additional study supplied by the NYSBA Report comprised six chapters (122 pp.) of appraisal of the American legal profession, four chapters (165 pp.) on the challenges to maintaining a single public profession of law, ${ }^{25}$ and two chapters (73 pp. plus appendices) of analysis of the principal issues together with specific recommendations.) Secondly, the NYSBA Report, completed in April and distributed in early May 2000, was timed to be

22 See ibid., at Chapter 12 and Appendices (beginning at p. 325) for its discussion of its recommendations.

23 Two of the Big Five are in litigation with the Netherlands Bar in Europe over the issue of whether integrated MDPs should be permitted. The case is now pending before the European Court of Justice. See Case C-309/99, C 299/15-16 [1999] Official Journal of the European Communities (16 October).

24 Reacting to the 1999 Report of the ABA Commission, the ABA House of Delegates so resolved by a vote of 304 to 98 .

25 One of these four chapters (pp. 185-291) consisted of a survey of MDP in 12 countries outside the US. 
available to members of the ABA House of Delegates preparing to consider MDP on 11 July 2000 (as discussed above). ${ }^{26}$ It would seem, therefore, that both the content and the timing of the NYSBA Report contributed to the positive reception that it received from many participants in the mid-2000 US debate on MDP.

One aspect of the content of the NYSBA Report would seem to merit comment in explaining the role it played in the mid-2000 debate. In contrast to the ABA Commission and the ABCNY, the NYSBA Report challenged the nature of MDP being promoted by the Big Five. According to the NYSBA Report, a Big Five MDP resembles not so much professionals from different professions working closely together and guided by enforceable codes of conduct, as it resembles virtually unregulated services offered by giant business conglomerates which, as regards the lawyers in their employ, tend to be indifferent to their actual status in the legal profession. ${ }^{27}$ A conclusion that can be reached from this analysis is that the Big Five may indeed offer, or seek to offer, the co-ordinated services of more than one profession, but they are also interested in acquiring ownership and control of the unidisciplinary practice of law for its own sake, and they pursue this interest in a manner that raises serious questions relating to the title topics of the NYSBA Report: the core values of the American legal profession; and the place of MDP in the law governing lawyers. The NYSBA Report thus provided substantive analysis for those participants in the mid-2000 debate who were inclined neither to accept nor to let pass in silence claims being made in respect of MDP as promoted by the Big Five.

While it can be said that the NYSBA Report proved relevant to the mid-2000 US debate on MDP and, in particular, the 11 July 2000 votes by the ABA House of Delegates, it remains to be seen whether its specific recommendations will be given effect in any of the US states, including New York. Both proponents and opponents of MDP may seek out arenas other than the ABA House of Delegates in which to carry on the future US debate on MDP. The result might be the adoption, but it also might lead to the by-passing, of the recommendations of the NYSBA Report. Positions are likely to be taken and measures are likely to be proposed along lines congenial to the professional or economic interest groups pursuing them. Scholarship, learning, and logic are grist for the writers and readers of reports, and they appear to have contributed immeasurably to the NYSBA Report. It would be

26 The timing was in fact determined by the ABA, which fixed an 25 April 2000 deadline for submissions to be considered by the House of Delegates in July. The NYSBA Committee met this deadline. (The ABA Commission issued its Report and Recommendation on 12 May 2000.) The Executive Committee and the House of Delegates of the NYSBA endorsed the NYSBA Report on, respectively, 28 April and 24 June 2000.

27 See NYSBA Report, at pp. 152-53, pp. 169-76. Ibid., at p. 369, mentions the claim by Ernst \& Young that its US affiliated law firm is separate from Ernst \& Young itself. In this connection, compare Ernst \& Young, 2000 Worldwide Corporate Tax Guide at Preface and pp. 696-697 (listing the law firm of McKee Nelson, Ernst \& Young LLP of Washington, $\mathrm{DC}$ as a member of Ernst \& Young International). 
foolhardy, however, to assume that they will necessarily control the politics and economics of those who would control the practice of law.

\section{Conclusion}

Politics and economics are likely to be major forces in the future US debate on MDP. As has been seen in the context of the Big Five, much of the debate revolves around ownership and control of the unidisciplinary practice of law, to which nonlawyers and non-legal entities aspire because legal practice is thought to be profitable. Its profitability is front-page news, ${ }^{28}$ and would seem to justify the views of the law and economics school, at least to the extent that law firms generate high returns on their capital. In any event, the economics of legal practice compete for the attention of the participants in the MDP debate, and may make for more interesting reading than the core values of the legal profession.

The economics of legal practice (like the economics of activities in general) is cyclical. At times when the ownership of legal practice is sufficiently profitable to make it seem attractive to non-lawyers and entities whose primary function is not legal practice, advocates of non-lawyer ownership of, and investment in, the practice of law may tend to overlook possible future downturns in profitability. They may also tend to underestimate the problems involved in transforming the exigencies of legal practice, the complexities of legal thinking, and the temperament of legal practitioners into profits. Economic cycles may in the end prove to be an ephemeral foundation for legal practice, and legal practitioners themselves may over time constitute the most stable source of capital for the legal profession. Economic caution, however, is unlikely to deter representatives of those schools of thought that, as a matter of doctrine (the law and economics school) or of self-interest (the Big Five) or of perceived social need (the ABCNY), urge that non-lawyers be permitted to own and invest in the practice of law.

Two questions thus arise - what are the professional rules that will apply to nonlawyers who own or otherwise control legal practices offering services to the general public, and who will be responsible for enforcing those rules? The law and economics school dismisses such rules as protectionist encroachments on the free marketplace. The Big Five do not seem to accept that they themselves (as distinguished from individual lawyers in their employ) should be subject to such rules when they are in ultimate control of such legal practices. The ABCNY feels that the ABA should convene a conference of concerned professionals to devise such rules on the basis of

See, e.g., Greg Winter, 'Legal Firms Cutting Back on Free Services for Poor' (2000) The New York Times, at A1 (top of page), 17 August (citing the 'rush of new business' to law firms, and high levels of minimum annual fee-paying hours per law firm associate). 
existing rules governing the affected professions. ${ }^{29}$ The flatly negative school would avoid these questions altogether by simply forbidding any form of MDP.

The NYSBA Report is essentially an analytical exercise that looks for answers to these questions in the law governing lawyers in the US. Because the other four schools of thought, for quite different reasons, are unlikely to be satisfied by this exercise, the NYSBA Report is open to attack on at least four fronts, and is vulnerable to the political allies of its detractors. In particular, the Big Five may feel challenged to create integrated MDPs in the US, rather than to shape their activities to conform with the 'side-by-side' model of MDP proposed by the NYSBA Report (discussed above) ${ }^{30}$ Similarly, bar groups opposed to any form of MDP may oppose the adoption of rules along the lines recommended by the NYSBA Report. Moreover, even if the recommendations of the NYSBA Report are adopted, their enforcement may prove less rigorous than the precision with which they were drafted. All of these disclaimers having been made, however, there remains the possibility that the NYSBA Report marks the beginning of a constructive search for answers to the basic questions of professional ethics raised by the on-going US debate over MDP.

29 The notion that some key to all deontologies can be found to solve the problem does not seem to be widely shared outside the ABCNY. (In literature, a comparable quest is found in Casaubon's search for the key to all mythologies in George Eliot's, Middlemarch.)

30 It can be noted that Donahue \& Partners of Toronto, Canada, known there as the "captive law firm' of Ernst \& Young, has opened a branch office in the Ernst \& Young offices in New York. 
